\title{
Sensitivity of the Amphipod Tiburonella viscana (Platyischnopidae) to $\mathrm{K}_{2} \mathrm{CR}_{2} \mathrm{O}_{7}$
}

\author{
Denis M. S. Abessa* and Eduinetty C. P. M. Sousa \\ Laboratório de Ecotoxicologia; Instituto Oceanográfico; Universidade de São Paulo; Praça do Oceanográfico, \\ 191; 05508-900; São Paulo - SP - Brazil
}

\begin{abstract}
The sensitivity of Tiburonella viscana to $\mathrm{K}_{2} \mathrm{Cr}_{2} \mathrm{O}_{7}$ was evaluated from 18 water-only toxicity tests. The mean $48 \mathrm{~h}$ LC50 was estimated as $11.217 \pm 3.768 \mathrm{mg} / \mathrm{l}$, and the warning limits were calculated (mean LC50 \pm 2 SD) as being between 3.68 and $18.75 \mathrm{mg} / \mathrm{l}$. These results are baseline for the species and can be used for future comparisons in toxicity tests.
\end{abstract}

Key words: Tiburonella viscana, potassium dichromate, Brazil, ecotoxicology

\section{INTRODUCTION}

The burrowing amphipod Tiburonella viscana is distributed along the Brazilian coast, being abundant on the shores of the State of São Paulo (Wakabara et al., 1991). The species has been used as a test organism in sediment toxicity tests since the early 90's (Melo, 1993). In the last decade, the use of sediment toxicity tests within monitoring programs and environmental evaluations has increased in Brazil (Abessa et al., 1998; Abessa et al., 2002). According to a guidance provided by the Environment Canada (1992), for each toxicity test an additional test with a reference substance should be conducted in order to estimate the condition of the test organisms, especially when field animals are used.

Sensitivity of $T$. viscana to reference toxicants was first reported by Melo (1993), but insufficient information was available to produce a warning chart. So, it is difficult to compare with any confidence data from different tests or even results obtained for other species. The objective of the present work was to propose a warning chart about the sensitivity of the amphipod $T$. viscana to $\mathrm{K}_{2} \mathrm{Cr}_{2} \mathrm{O}_{7}$. It could be useful as a basis for comparisons to the results obtained in further toxicity tests with this species.

\section{MATERIALS AND METHODS}

The amphipods were collected at the Engenho D’Água Beach, São Sebastião Island $\left(23^{\circ} 48^{\prime}\right.$ S $45^{\circ} 22^{\prime} \mathrm{W}$ ), and acclimatized for three days in laboratory. Eighteen water-only toxicity tests with $\mathrm{K}_{2} \mathrm{Cr}_{2} \mathrm{O}_{7}$ were conducted with $T$. viscana, following the procedure recommended by the Environment Canada (1992) for reference substances. The working concentrations were prepared by dilution of a previously made standard solution $1000 \mathrm{mg} / \mathrm{l}$ in seawater. For the first two tests, the following concentrations were prepared: $1.0 ; 2.2 ; 4.6 ; 10 ; 22$ and $46 \mathrm{mg} / 1$, whereas for the

* Author for correspondence 
rest of the experiments the test concentrations were $3.12 ; 6.25 ; 12.5$ and $25 \mathrm{mg} / \mathrm{l}$. The controls were exposed to filtered seawater. For each concentration, 3 to 5 replicates were prepared, in glass beakers containing $350 \mathrm{ml}$ solution and 10 adults. Juveniles and ovigerous females were not used. The system was maintained at constant temperature $\left(25 \pm 2{ }^{\circ} \mathrm{C}\right)$ with continuous lighting. After 48 hours, the survival in each replicate was observed and the $48 \mathrm{~h}-\mathrm{LC} 50$ was estimated by the Trimmed Spearman-Karber method with Abbot's correction (Hamilton et al., 1977).

\section{RESULTS AND DISCUSSION}

The results are presented in the Figure 1. The mean 48h-LC50 was estimated as $11.217 \pm 3.768$ $\mathrm{mg} / \mathrm{l}$, which was comparable to the values obtained by Melo (1993) for this species and by Bryant et al. (1984) for Corophium volutator, which were 4.9-7.0 and 5.4-100.0 mg/l, respectively. The coefficient of variation calculated for the LC50s was $33.60 \%$, showing that the sensitivity of $T$. viscana to $\mathrm{K}_{2} \mathrm{Cr}_{2} \mathrm{O}_{7}$ did not seem to vary substantially among tests. This value was close to the $30 \%$ recommended by the Environment Canada (1992).

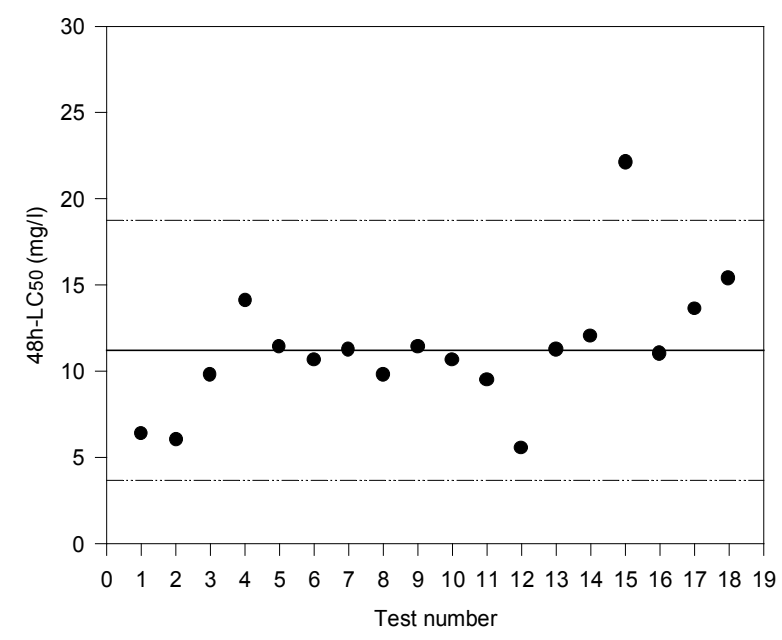

Figure 1 - Warning chart for T. viscana showing the results of 18 toxicity tests (expressed as $48 \mathrm{~h}$ LC50), the mean 48h-LC50 and the upper and lower intervals.
Using these results, the upper and lower warning limits for tests with $\mathrm{K}_{2} \mathrm{Cr}_{2} \mathrm{O}_{7}$ were calculated (mean LC50 \pm 2 SD), which were 3.68 and 18.75 $\mathrm{mg} / \mathrm{l}$, respectively. Any 48h-LC50 value falling outside of the warning limits will indicate that the sensitivity of the amphipods or the test system is suspect. However, according to Environment Canada (1992), there is a $5 \%$ natural probability of outer values to occur due to chance alone. Then, an outlying LC50 does not necessarily mean that the test is invalid but does indicate that the test conditions should be carefully evaluated, and in some cases, a new population must be collected and the test repeated.

\section{ACKNOWLEDGEMENTS}

Authors are grateful to Dr Robert Scott Carr for suggestions, Dr Salvador Ayrton Gaeta for help with the figure, FAPESP for the financial support (proc. $\mathrm{n}^{\circ}$ 98/00808-6).

\section{RESUMO}

Nos últimos anos, o anfípodo Tiburonella viscana tem sido amplamente utilizado em estudos de avaliação da qualidade de sedimentos marinhos. Neste trabalho, foi avaliada a sensibilidade dessa espécie ao dicromato de potássio, composto utilizado como substância de referência, a partir de 18 testes de toxicidade. A CL50-48h média foi estimada em 11,217 $\pm 3,768 \mathrm{mg} / 1 \mathrm{~K}_{2} \mathrm{Cr}_{2} \mathrm{O}_{7}$, e os limites de aceitabilidade para essa substância foram calculados (LC50 média $\pm 2 \mathrm{DP}$ ), estando entre 3,68 e $18,75 \mathrm{mg} / \mathrm{l}$. Os resultados poderão ser utilizados em futuras comparações, quando da realização de testes de toxicidade com $T$. viscana.

\section{REFERENCES}

Abessa, D. M. S.; Sousa, E. C. P. M.; Rachid, B. R. F. and Mastroti, R. R. (1998), Use of the burrowing amphipod Tiburonella viscana as a tool in marine sediments contamination assessment. Braz. Arch. Biol. Technol., 41 : (2), 225-230.

Abessa, D. M. S.; Sousa, E. C. P. M.; Rachid, B. R. F. and Mastroti, R. R. (2002). Toxicity of sediments from Santos estuary (SP, Brazil): preliminary results. Ecotoxicol. Environ. Restor. [In press]. 
Environment Canada. (1992), Biological test method: acute test for sediment toxicity using marine or estuarine amphipods. Report EPS 1/RM/26. Environment Canada, Ottawa..

Hamilton, M. A.; Russo, R. C. and Thurston, R. V. (1977), Trimmed Spearman-Karber method for estimating median lethal concentrations in toxicity bioassays. Environ. Sci. Technol., 11: (7), 714-719. Correction (1978), 12 : (4), 417.

Melo, S. L. R. (1993), Testes de Toxicidade com sedimentos marinhos: adequação de metodologia para o anfípodo escavador Tiburonella viscana. Master of Science Dissertation. Universidade de São Paulo, São Carlos - SP.
Wakabara, Y.; Tararan, A. S.; Valério-Belardo, M. T.; Duleba, W. and Leite, F. P. P. (1991), Gammaridean and caprelidean from Brazil. Hydrobiologia, 223, 69-77.
Received: November 07, 2001; Revised: February 19, 2002; Accepted: July 01, 2002. 